\title{
Improvement of the growth, yield, and tuber quality of purple yam through macro and micronutrient fertilization
}

\author{
Anabella B. Tulin \\ Philippine Root Crop Research and Training Center, Visayas State University, Visca, \\ Baybay, Leyte 6521-A, Philippines
}

\begin{abstract}
The high demand for yam as food and for industry calls for the development of new technologies and innovations that will increase yam production. This study was conducted to assess the effects of the addition of different levels of micronutrient fertilizers (Biozome-200 micronutrient soil conditioner) to NPK fertilizers on the growth and yield of purple yam. Seven sets of experiments were conducted in six years employing different fertilizer treatments representing five levels of inputs. Purple yam (VU - 2 variety) was used as planting materials and these were planted at a distance of $1 \mathrm{~m} \mathrm{X} 50$ $\mathrm{cm}$ at a depth of $10 \mathrm{~cm}$.

Results showed that addition of 4 to $16 \mathrm{~kg} / \mathrm{ha}$ of Biozome- 200 to $150-50-150$ $\mathrm{kg} / \mathrm{ha}$ of NPK fertilizers produced significantly bigger yams and higher plant biomass as compared to the unfertilized plots and those applied with NPK fertilizers only. Total tuber yields ranging from 15 tons to 26 tons/ha was obtained through the application of $150-50-150 \mathrm{~kg} / \mathrm{ha} \mathrm{N}-\mathrm{P}_{2} \mathrm{O}_{5}-\mathrm{K}_{2} \mathrm{O}+4$ to $16 \mathrm{~kg} / \mathrm{ha}$ Biozome- 200 using 100 gm tuber setts as planting materials. In terms of tuber quality, plant tissue analysis of tubers showed that purple yams that were fertilized with macro and micronutrients have higher amounts of total $\mathrm{N}, \mathrm{K}, \mathrm{Zn}, \mathrm{Ca}, \mathrm{Mg}, \mathrm{Fe}, \mathrm{Mn}$, and $\mathrm{Cu}$ as compared to the unfertilized plants. These results implied the improvement of the nutritional content of purple yam tubers with macro and micronutrient addition.
\end{abstract}

Keywords: purple yam, macronutrients, micronutrients, yield, income.

Correspondence: A. B. Tulin. Address: Philippine Root Crop Research and Training Center, Visayas State University, Visca, Baybay, Leyte 6521-A, Philippines Telephone (53) 335-2616 E-mail: belle2460@yahoo.com.

DOI: $10.32945 /$ atr3125.2009 


\section{INTRODUCTION}

The declining yield growth for major food crops coupled with the declining soil fertility have raised much concerns about agriculture's ability to feed a world population that is expected to exceed 7.5 billion by the year 2020 (Scott et al., 2000). Future strategies for increasing agricultural productivity will have to focus on using available nutrient resources more efficiently, effectively, and sustainable than in the past. This calls for the establishment of proper balance between the nutrient requirements of plants and the nutrient reserves in the soils which is essential in maintaining high yields and soil fertility and in sustaining agricultural productivity over a longer period of time.

In the Philippines, root crops are considered as a major staple food next to rice and lately they are highly demanded in industry as source of feeds, starch and biofuels. One of these root crops that has gained popularity is yam (Dioscorea alata L.). Among the different varieties of yam, the purple variety is the most popular in the country because of its many uses. It is usually processed into food products like jam, "halaya", ice cream, yoghurt, "hopia", "piyaya", cakes, pastries and breads. The big demands for yam are in ice-cream and as powder or puree which are marketed abroad. Lately, the high anthocyanin content of purple yam made them very popular as health food and they are processed as heart tablets and wine. In addition, the latest findings of the Biotechnology team at PhilRootcrops have shown that purple yam possessed a special type of protein that has antihypertensive property (Tulin and Ecleo, 2008). This gave added value to purple yams which make them as a potential novel medicine for hypertension and other immune related disease like diabetes. Aside from these, yam production is also essential to the survival and well being of many generations of people in the tropics and continues to be highly important for ensuring sustainable food security and income generation (Scott et al., 2000).

Rootcrops are good source of protein such as sweetpotato which has an average protein concentration comparable to rice (Woolfe, 1992). It is also a good source of vitamin A, calcium, vitamin C, beta-carotene, thiamine, riboflavin and folic acid (Villareal et al., 1985). Purple yam, on the other hand is rich in anthocyanin, which is a well-known antioxidant aside from its high protein, carbohydrates, potassium and iron content. 
One of the major constraints for yam production in the Philippines is the lack of planting materials since the harvested tubers are usually used as planting materials. This is further aggravated by the very low yields at the farmers' field since most farmers usually do not apply fertilizers to purple yam thereby greatly reducing their yield. These production constraints greatly reduce yam yield thereby giving the farmers low economic returns since part of the tuber yield are still being utilized as planting materials. The reported national average of yam is 5 tons/ha which is very low and very uneconomical considering the high production cost of yam.

The low yam yields could be attributed to the very limited amount of fertilizers applied especially at the farmers field. In fact since yam could grow in a wide range of soil (from acidic to alkaline), farmers usually neglect the need to apply fertilizers to yam. They are usually planted in areas that are not suitable to other major crops such as rice and corn.

Yam like other crops, require essential elements in order to grow properly. The essential elements taken up by plants from the soil and include the macronutrients nitrogen $(\mathrm{N})$, phosphorus $(\mathrm{P})$, potassium $(\mathrm{K})$, calcium $(\mathrm{Ca})$, magnesium $(\mathrm{Mg})$, and sulfur $(\mathrm{S})$ and the micronutrients such as boron $(\mathrm{B})$, chlorine $(\mathrm{Cl})$, copper $(\mathrm{Cu})$, iron $(\mathrm{Fe})$, manganese $(\mathrm{Mn})$, molybdenum (Mo) and zinc (Zn) (McKenzie, 1992). Plants growth and development will be greatly impaired if any of these elements is lacking in the soil or is not adequately balanced with other nutrients (Bell et al., 2004). Inadequate micronutrient status of crops limit growth and when unrecognized it not only has a direct effect on crop developments but it reduces the efficiency of using macronutrient fertilizer (Kirkby and Roemheld, 2004). The absence of micronutrient fertilizers results in inadequate absorption of trace elements by plants, which cause substantial yield losses in different crops and forages, and eventually results in poor health for domestic animals and humans (Malakouti, 2008). The problem can only be corrected by increasing the supply of that nutrients ( $\mathrm{O}^{\prime}$ Sullivan et al., 1997). Amounts of $\mathrm{N}$ or $\mathrm{P}$ for example cannot compensate for a deficiency of Fe or B. Because of this, plant nutritionists, soil scientists and agronomists have shown increasing interest on micronutrients because of their importance in crop production. Moreover there is increasing 
awareness on the important contribution of micronutrients in the health of the soil, crop, human and animal ecosystem.

One of the commercially available sources of micronutrient that is affordable to farmers is Biozome-200. This costs only P500 for $4 \mathrm{~kg}$ of Biozome -200. Biozome-200 is a rich source of micronutrients such as $\mathrm{Mn}(4 \%), \mathrm{Zn}(4.8 \%)$, Iron (1.1\%), Cu (1.2\%), B (0.6\%). It also contains $\operatorname{Mg}(4.5 \%)$ and $\mathrm{S}(17.5 \%)$.

In order to obtain higher yields in yam, innovations that will warrant and assure higher yields and economic returns should be developed to ensure the sustainability of yam production and to encourage more farmers and entrepreneurs to venture into yam production. This should take into consideration, the best combination of macro and micronutrients that will warrant higher income and income for our farmers and yam endusers. There is also a need to evaluate the effects of fertilization on the tuber quality of purple yam to give more value to the crop and to encourage more farmers to engage in yam production to meet the great demand for purple yam in industry.

This study evaluated the effects of the different levels of macro and micronutrient fertilizers on the growth, yield and tuber quality of purple yam. It also determined the most economical levels of macro and micronutrient fertilizers needed to attain higher yields of purple yam.

\section{MATERIALS AND METHODS}

\section{Field set-up and fertilizer treatments}

Five sets of field experiments were set-up simultaneously in a period of 5 years in a 500 sq. $\mathrm{m}$ area using the recommended practices for land preparation and planting for yam. All in all, this covered 7 cropping seasons of yam because in some years (like in 2003, 2004 and 2006), two experimental set-ups were established. One hundred gm tuber setts of yam (VU-2 var.) were used as planting materials. They were planted at a distance of $1 \mathrm{~m} \mathrm{X} 50 \mathrm{~cm}$ at a depth of $10 \mathrm{~cm}$. The experimental setup is shown below in Fig 1.

Different levels of fertilizers were applied representing varying levels 
of macro and micronutrient fertilizers. The sources of macronutrient fertilizers include complete fertilizer (14-14-14), muriate of potash (60\% $\left.\mathrm{K}_{2} \mathrm{O}\right)$ and urea $(45 \% \mathrm{~N})$. For micronutrient fertilizer, Biozome-200, a commercially available micronutrient soil conditioner was used. Biozome200 was chosen since it contain a rich source of micronutrient such as Mn (4\%), Zn (4.8\%), Iron (1.1\%), Cu (1.2\%), B (0.6\%). It also contain $\mathrm{Mg}(4.5 \%)$ and $\mathrm{S}(17.5 \%)$ which are sources of secondary macronutrients.

Various fertilizer treatment combinations were employed to determine the most profitable levels of macro and micronutrients for yam production and they are presented as follows:

Set A (using maximum inputs or high level of soil amendments and $100 \mathrm{gm}$ of tuber setts conducted for two cropping seasons. The treatments as follows: $\mathrm{T}_{0}$ - control (no fertilizer); $\mathrm{T}_{1}-150-50-150 \mathrm{~kg} / \mathrm{ha} \mathrm{N}-\mathrm{P}_{2} \mathrm{O}_{5}$ $\mathrm{K}_{2} \mathrm{O} ; \mathrm{T}_{2}-\mathrm{T}_{1}+4 \mathrm{~kg} / \mathrm{ha}$ Biozome $-200 ; \mathrm{T}_{3}-\mathrm{T}_{1}+8 \mathrm{~kg} / \mathrm{ha}$ Biozome -200 ; and $\mathrm{T}_{4}-\mathrm{T}_{1}+16 \mathrm{~kg} /$ ha Biozome- 200 .

Set B (using maximum inputs but included a treatment of micronutrient only and 100 gm tuber setts) conducted for one cropping season. The various treatments were as follows: $\mathrm{T}_{0}$ - control (no fertilizer); $\mathrm{T}_{1}-150-50-150 \mathrm{~kg} / \mathrm{ha} \mathrm{N}-\mathrm{P}_{2} \mathrm{O}_{5}-\mathrm{K}_{2} \mathrm{O} ; \mathrm{T}_{2}-16 \mathrm{~kg} / \mathrm{ha}$ Biozome -200 only; $\mathrm{T}_{3}-\mathrm{T}_{2}+8 \mathrm{~kg} / \mathrm{ha}$ Biozome -200 ; and $\mathrm{T}_{4}-\mathrm{T}_{2}+16 \mathrm{~kg} / \mathrm{ha}$ Biozome- 200 .

Set $\mathrm{C}$ (using minimum inputs or reduced level of soil amendments and 100 gm tuber setts) conducted for two cropping seasons. The different treatments were as follows: $\mathrm{T}_{0}$ - control (no fertilizer); $\mathrm{T}_{1}-75-25-75(\mathrm{~N}$ $\left.-\mathrm{P}_{2} \mathrm{O}_{5}-\mathrm{K}_{2} \mathrm{O}\right) ; \mathrm{T}_{2}-\mathrm{T}_{1}+4 \mathrm{~kg} /$ ha Biozome -200 only; $\mathrm{T}_{3}-\mathrm{T}_{1}+8 \mathrm{~kg} / \mathrm{ha}$ Biozome -200; and $\mathrm{T}_{4}-\mathrm{T}_{1}+16 \mathrm{~kg} /$ ha Biozome-200. The fertilizers were applied once at planting. The experimental set-up were laid out in the field using RCBD design replicated 4 times.

Set $\mathrm{D}$ (using minimum and maximum inputs and $100 \mathrm{gm}$ tuber setts) conducted for one cropping season. The different treatments were as follows: $\mathrm{T}_{0}$ - control (no fertilizer); $\mathrm{T}_{1}-75-25-75 \mathrm{~kg} / \mathrm{ha} \mathrm{N}-\mathrm{P}_{2} \mathrm{O}_{5}-\mathrm{K}_{2} \mathrm{O}$; $\mathrm{T}_{2}-150-50-150 \mathrm{~kg} / \mathrm{ha} \mathrm{N}-\mathrm{P}_{2} \mathrm{O}_{5}-\mathrm{K}_{2} \mathrm{O} ; \mathrm{T}_{3}-\mathrm{T}_{1}+8 \mathrm{~kg} /$ ha Biozome -200 ; and $\mathrm{T}_{4}-\mathrm{T}_{1}+8 \mathrm{~kg} /$ ha Biozome- 200 .

Set E (using maximum inputs and the combination of maximum and minimum inputs and $100 \mathrm{gm}$ tuber setts) conducted for one cropping season. The different treatments were as follows: $\mathrm{T}_{0}$ - control (no fertilizer); $\mathrm{T}_{1}-150-50-150 \mathrm{~kg} / \mathrm{ha} \mathrm{N}-\mathrm{P}_{2} \mathrm{O}_{5}-\mathrm{K}_{2} \mathrm{O} ; \mathrm{T}_{2}-225-75-225 \mathrm{~kg} / \mathrm{ha}$ 


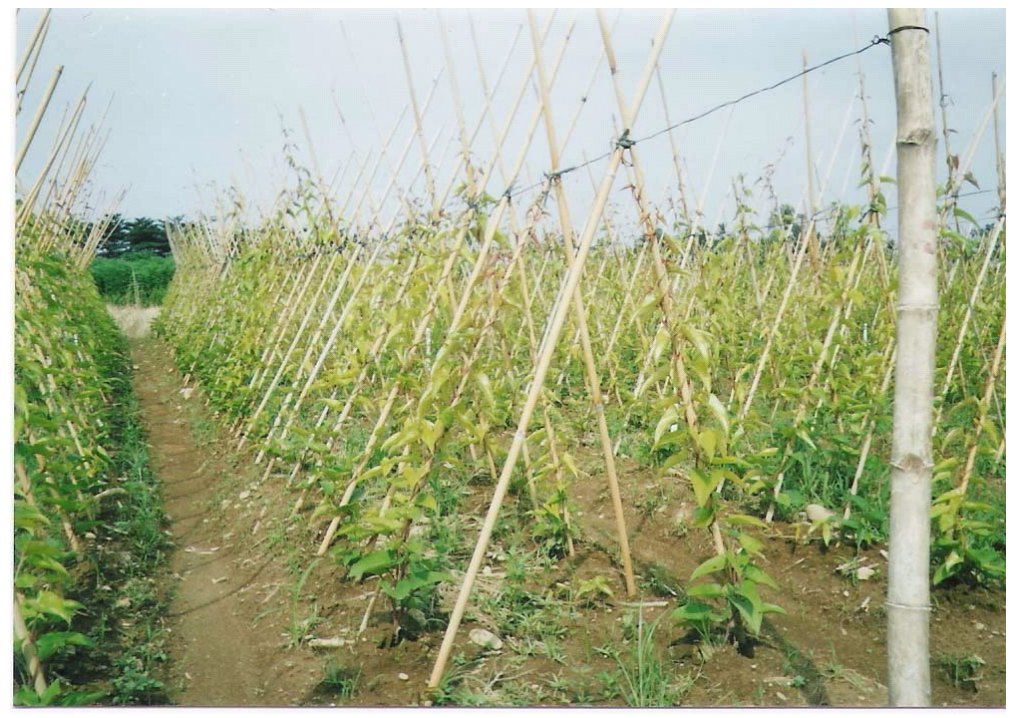

Figure 1. The field experimental set-up 
$\mathrm{N}-\mathrm{P}_{2} \mathrm{O}_{5}-\mathrm{K}_{2} \mathrm{O} ; \mathrm{T}_{3}-\mathrm{T}_{1}+8 \mathrm{~kg} /$ ha Biozome -200 ; and $\mathrm{T}_{4}-\mathrm{T}_{2}+8 \mathrm{~kg} / \mathrm{ha}$ Biozome-200.

For each cropping, the fertilizers were applied once at planting. The experimental set-up were laid out in the field using RCBD design replicated 4 times. The plants were also closely monitored to check for the growth of weeds on the area and the appearance of anthracnose. Whenever necessary, the plants were sprayed with fungicide to prevent the attack and damage of anthracnose. Yam was allowed to grow for a period of 8 months, from May to January which is the normal cropping season for yam.

\section{Soil chemical characterization}

\section{Soil collection and preparation}

Soil sampling was conducted in the area prior to the establishment of each experimental set-up for initial soil characterization. In choosing the experimental areas that were used for each cropping, considerations were made on the uniformity of the area in terms of slope and other soil characteristics. Sampling was done by collecting 10 composite samples per area using an auger following the standard procedure (PCARR, 1980). Soil samples were taken from the surface layers with a depth of $0-20$ $\mathrm{cm}$. The soil samples were then thoroughly mixed. A one kilogram composite soil sample was set aside, air-dried, pulverized and sieved through a 2-mm wire mesh for analyses of soil chemical properties.

\section{Soil chemical analyses}

Soil $\mathrm{pH}$ was analyzed using the potentiometric method in water and $\mathrm{KCl}$ using 1:2.5 soil-water/KCl ratio (ISRIC, 1995). Soil organic matter (\%) was analyzed by the use of modified Walkley-Black Method (Jackson, 1958). Extractable P was analyzed using Bray No.2 method and quantified by the method of Murphy and Riley (1962). Exchangeable $\mathrm{Ca}$ and $\mathrm{Mg}$ were extracted using $1 \mathrm{~N} \mathrm{NH}_{4} \mathrm{OAC}$ at $\mathrm{pH}$ 7.0. Magnesium and calcium were quantified by atomic absorption spectrometry (AAS) using Varian Spectrophotometer (Varian Australia Pty. Lmt, 2002) according to the 
procedure of Schlichting et al., (1995). Exchangeable Al was analyzed using $1 \mathrm{~N} \mathrm{KCl}$ as extractant and quantified by titrating the resulting extract with $0.1 \mathrm{~N} \mathrm{NaOH}$ (Thomas, 1982). Cation Exchange Capacity was analyzed using $1 \mathrm{~N} \mathrm{NH}_{4} \mathrm{OAc}$ adjusted to $\mathrm{pH}$ 7.0. Adsorbed ammonium was replaced with sodium ions using $10 \%$ acidified $\mathrm{NaCl}$. The leachate was distilled using a Kjeldahl distilling apparatus and the distillate was titrated with a standard $0.05 \mathrm{~N} \mathrm{H}_{2} \mathrm{SO}_{4}$ (ISRIC, 1995).

\section{Plant tissue analyses}

Digestion procedure for the determination of total calcium, magnesium, potassium, sodium and iron in plants published by the University of Florida (Mylavarapu and Kennelley, 2002) was used as follows:

1.One gram of ground and oven-dried plant sample was weighed into a crucible and placed in a muffle furnace set at $550^{\circ} \mathrm{C}$ temperature.

2.Plant samples were allowed to ash for a minimum of 5 hours (ashing time should not exceed 16 hours) and cooled.

3.The ash was moistened with 5 drops deionized water followed by the addition of $5 \mathrm{ml} 6 \mathrm{M}$ hydrochloric acid. Suspension was allowed to stand for 30 minutes.

4.The suspension was transferred into a $50 \mathrm{ml}$ volumetric flask, diluted with deionized water and filtered using whatman $\# 42$ filter paper.

5.An aliquot of $0.5 \mathrm{ml}$ was mixed with $2.5 \mathrm{~mL} 10,000 \mathrm{ppm}$ strontium chloride for $\mathrm{Ca}$ and $\mathrm{Mg}$ and $1 \mathrm{~mL}$ of 50,000 ppm cesium chloride and diluted to $25 \mathrm{ml}$ with deionized water.

6. Samples were read for total calcium, total magnesium, total sodium and total potassium at a wavelength of 239.9, 202.6, 589.0 and $769.9 \mathrm{~nm}$ respectively.

7. While total iron ( $372.0 \mathrm{~nm})$, copper $(327.4 \mathrm{~nm})$, manganese (403.1 $\mathrm{nm})$, was read in the AAS. 
Readings were converted into elemental concentrations using the equation:

$$
\begin{aligned}
& \mathrm{C}=\frac{\mathrm{RV}}{\mathrm{W}} \\
& \text { Where: } \mathrm{C}=\text { conc. of the metal being analyzed }(\mathrm{mg} / \mathrm{kg} \text { soil }) \\
& \mathrm{R}=\mathrm{AAS} \text { reading }(\mathrm{ppm}) \\
& \mathrm{V}=\text { volume of the solution }(\mathrm{ml}) \\
& \mathrm{W}=\text { weight of sample used }(\mathrm{g})
\end{aligned}
$$

Analysis of data

Data on growth and yield parameters were analyzed using standard ANOVA following randomized complete block design (RCBD). Mean comparison within treatments was performed using least significant differences (LSD) at $\mathrm{p}=0.05$.

\section{RESULTS AND DISCUSSION}

\section{Effects of macro and micronutrients on the growth of purple yam}

Figures 2 to 3 showed the growth of purple yam as affected by the application of macro and micronutrients fertilizers under different levels of inputs. Highest plant height was obtained in $\mathrm{T}_{4}$ when yam received maximum inputs of $150-50-150 \mathrm{~kg} \mathrm{~N}-\mathrm{P}_{2} \mathrm{O}_{5}$ and $\mathrm{K}_{2} \mathrm{O}$ with $16 \mathrm{~kg} / \mathrm{ha}$ of Biozome-200. It was further observed that the plants in the control (without fertilization) showed significantly poor growth performance as compared to those with fertilizer treatments (Figure 2). This was indicated by the yellowing of leaves and smaller leaf sizes (Figure 3). On the other hand, bigger and healthier leaves were obtained in yam receiving maximum inputs (Figure 3). The highest plant height obtained at $31 / 2$ month after planting for Set A experiment was obtained in $T_{4}$ followed by $\mathrm{T}_{3}$ and $\mathrm{T}_{2}$ in descending order (Table 1 ). The results obtained in $\mathrm{T}_{4}$ and $\mathrm{T}_{3}$ were statistically similar which indicate that an addition of $8 \mathrm{~kg} / \mathrm{ha}$ of micronutrient fertilizer is sufficient to warrant an $83 \%$ increase in plant height as compared to the control. These results implied the important 


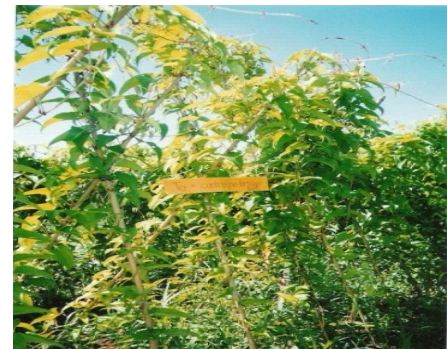

$\mathrm{T}_{0}$

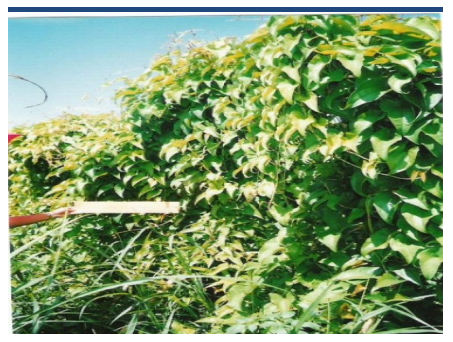

$\mathrm{T}_{3}$

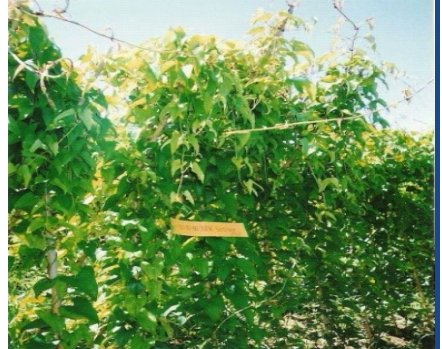

$\mathrm{T}_{1}$

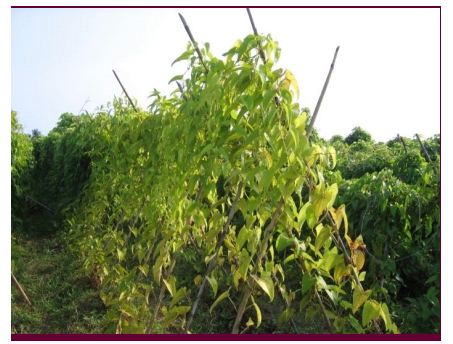

$\mathrm{T}_{4}$

Figur. 2. The growth of purple yam as affected by different levels of macro and micronutrients (Set A). $\mathrm{T}_{0}$ - control; $\mathrm{T}_{1}-150-50-150 \mathrm{~kg} / \mathrm{ha} \mathrm{N}-\mathrm{P}_{2} \mathrm{O}_{5}-\mathrm{K}_{2} 0 ; \mathrm{T}_{3}-\mathrm{T}_{1}$ $+8 \mathrm{~kg} / \mathrm{ha}$ Biozome-200; $\mathrm{T}_{4}-\mathrm{T}_{1}+16 \mathrm{~kg} / \mathrm{ha}$ Biozome-200

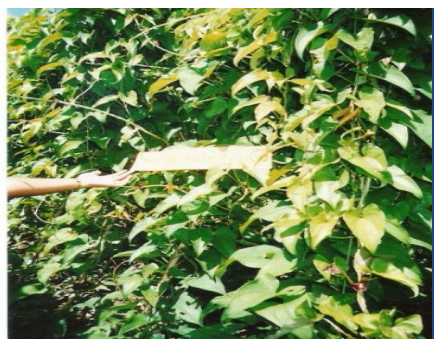

$\mathrm{T}_{0}$

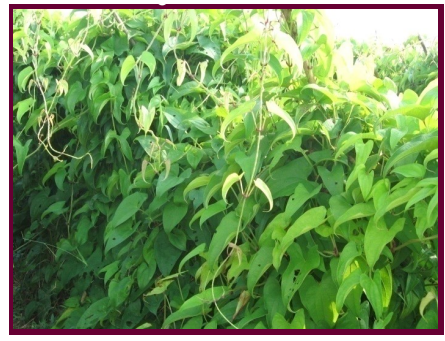

$\mathrm{T}_{3}$

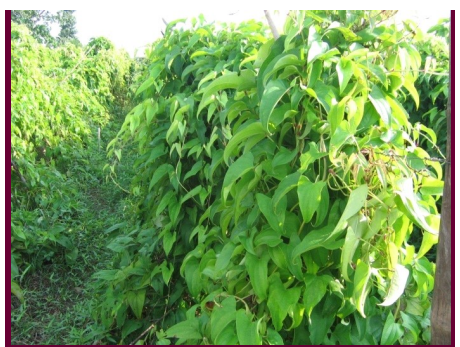

$\mathrm{T}_{1}$

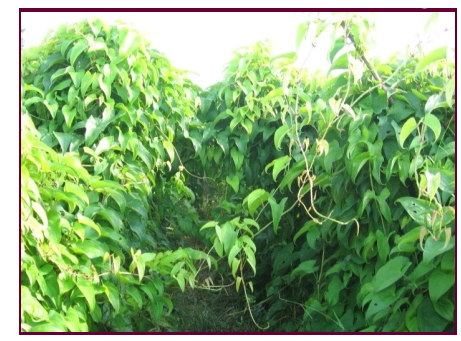

$\mathrm{T}_{4}$

Figure 3. The growth of purple yam as affected by different levels of macro and micronutrients (Set C). $\mathrm{T}_{0}$ - control; $\mathrm{T}_{1}-150-50-150 \mathrm{~kg} / \mathrm{ha} \mathrm{N}-\mathrm{P}_{2} \mathrm{O}_{5}-\mathrm{K}_{2} 0 ; \mathrm{T}_{3}-\mathrm{T}_{1}$ $+8 \mathrm{~kg} / \mathrm{ha}$ Biozome-200; $\mathrm{T}_{4}-\mathrm{T}_{1}+16 \mathrm{~kg} / \mathrm{ha}$ Biozome-200 
Table 1. Plant height $(\mathrm{cm})$ of purple yam at $31 / 2$ month after planting as affected by different levels of macro and micronutrient fertilizers (Set $\mathrm{A}-1^{\text {st }}$ cropping)

\begin{tabular}{lc}
\hline Treatments & Average plant height $(\mathrm{cm})$ \\
\hline $\mathrm{T}_{0}-$ control & $492 \mathrm{c}$ \\
$\mathrm{T}_{1}-150-50-150 \mathrm{~kg} / \mathrm{ha} \mathrm{N}-\mathrm{P}_{2} \mathrm{O}_{5}-\mathrm{K}_{2} 0$ & $520 \mathrm{bc}$ \\
$\mathrm{T}_{2}-\mathrm{T}_{1}+4 \mathrm{~kg} / \mathrm{ha} \mathrm{Biozome}-200$ & $572 \mathrm{ab}$ \\
$\mathrm{T}_{3}-\mathrm{T} 1+8 \mathrm{~kg} / \mathrm{ha}$ Biozome- 200 & $591 \mathrm{a}$ \\
$\mathrm{T}_{4}-\mathrm{T}_{1}+16 \mathrm{~kg} /$ ha Biozome-200 & $618 \mathrm{a}$ \\
\hline
\end{tabular}

contribution of macro and micronutrients for the enhancement of the growth performance of purple yam which has an important bearing on the translocation of photosynthates from the leaves to the roots. Micronutrients act as catalysts to many biochemical reactions that ensure plant growth and survival (Phillips, 2002). For example, boron is essential for cell division, zinc is required in the production of growth hormone auxin which is essential for photosynthesis and iron is important in chlorophyll synthesis and formation. Phillips further emphasized the importance of micronutrients for plant growth, that is, if they are not present, the plant will not survive.

\section{Effects of macro and micronutrients on the yield of and income derived from purple yam}

Table 2-8 present the effects of macro and micronutrients on the yield and income derived from purple yam under different levels of inputs. In comparing the different treatment combinations, results showed that for Set A (first and second cropping), generally the application of maximum inputs of macro and micronutrient fertilizers $\left(\mathrm{T}_{4}\right)$ gave the highest yield as compared to $\mathrm{T}_{0}, \mathrm{~T}_{1}, \mathrm{~T}_{2}$ and $\mathrm{T}_{3}$. Although in terms of yield, $\mathrm{T}_{2}, \mathrm{~T}_{3}$ and $\mathrm{T}_{4}$ are statistically similar, the net income that could be derived from each treatment varies significantly. In Set A first cropping, the highest yield obtained was 18.52 tons / ha $\left(\mathrm{T}_{4}\right)$ and this increased the yield by about $163 \%$ from the control which is only 11.32 tons/ha (Table 


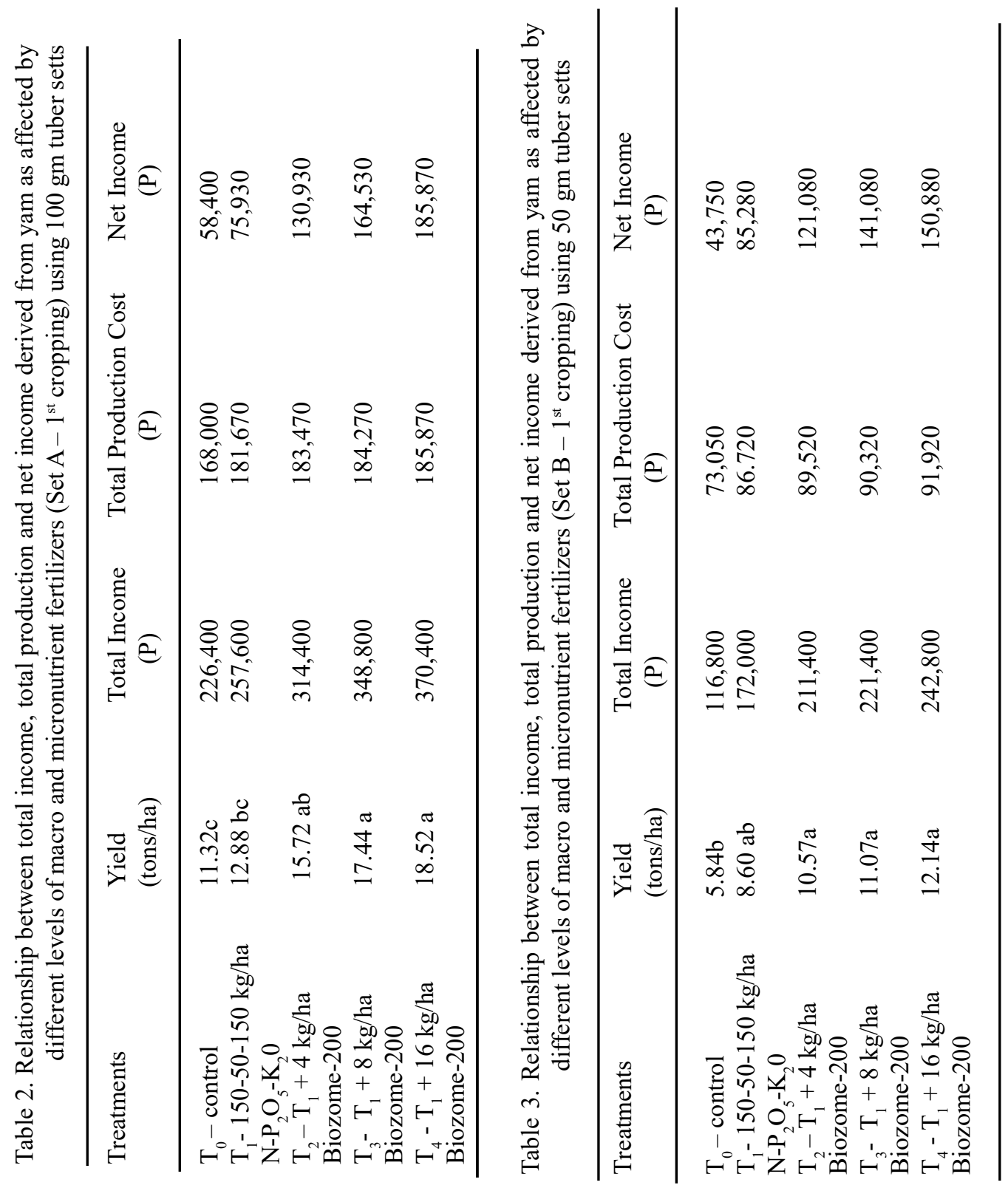


2). However if we based it on the national average yield value of 5 tons/ ha, this will give an increase of about $370 \%$. In terms of economic returns, this is equivalent to about $\mathrm{P} 185,000$ of net income per cropping (Table 2). On the second year, when the production cost was reduced the net income obtained was further increased to about P258,000 per cropping (Table 3). The significant effects of micronutrient addition to macronutrients on yield could be attributed to the enhancement of the efficiency of use of the macronutrient fertilizers by micronutrients (Kirkby and Roemheld (2004). The small investment incurred on fertilizer addition gave a highly significant increased on the net income obtained. This result was further supported by the findings of Diby et al (2006) that fertilizer application increased the dry matter production of two species (Dioscorea alata and Dioscorea rotundata) of yam. In wheat, the application of micronutrient-enriched NPK fertilizers provided a double benefit: increasing grain yield and improving the nutritional quality of harvested grains, since micronutrient-enriched NPK fertilizers also increase the concentration of micronutrients in grain (Malakouti, 2008).

In comparing the 6 levels of inputs, results indicated that in terms of tuber sett sizes (Set A and B), those receiving maximum inputs and used 100 gms of tuber setts (Sets A) significantly gave higher tuber yields as compared to the treatments that uses only 50 gms of tuber setts (Sets B). Comparing the results presented in Table 3 and 4 with the same production cost and fertilizer inputs, the highest tuber yield in Set A for $\mathrm{T}_{4}$ was 19 tons/ha (Table 3) while that of Set $\mathrm{B}$ for the same treatment is only 12.14 tons/ha (Table 4 ). In terms of economic returns, the net income was also reduced by almost half. The highest income in $\mathrm{T}_{4}$ using $100 \mathrm{gm}$ tuber setts was at 258,080 while for 50 gm tuber setts the net income was drastically reduced to P120,000. Although the cost of production was reduced by P30,000, this could not offset the great reduction in total net income. This implied the importance of choosing the right tuber sett sizes in the propagation of yam because bigger tuber setts have relatively higher amounts of stored food which can be used by yam in its growth and development.

In terms of the effects of micronutrient addition on the yield and economic returns (Set C, Table 5), results showed that for the treatment 

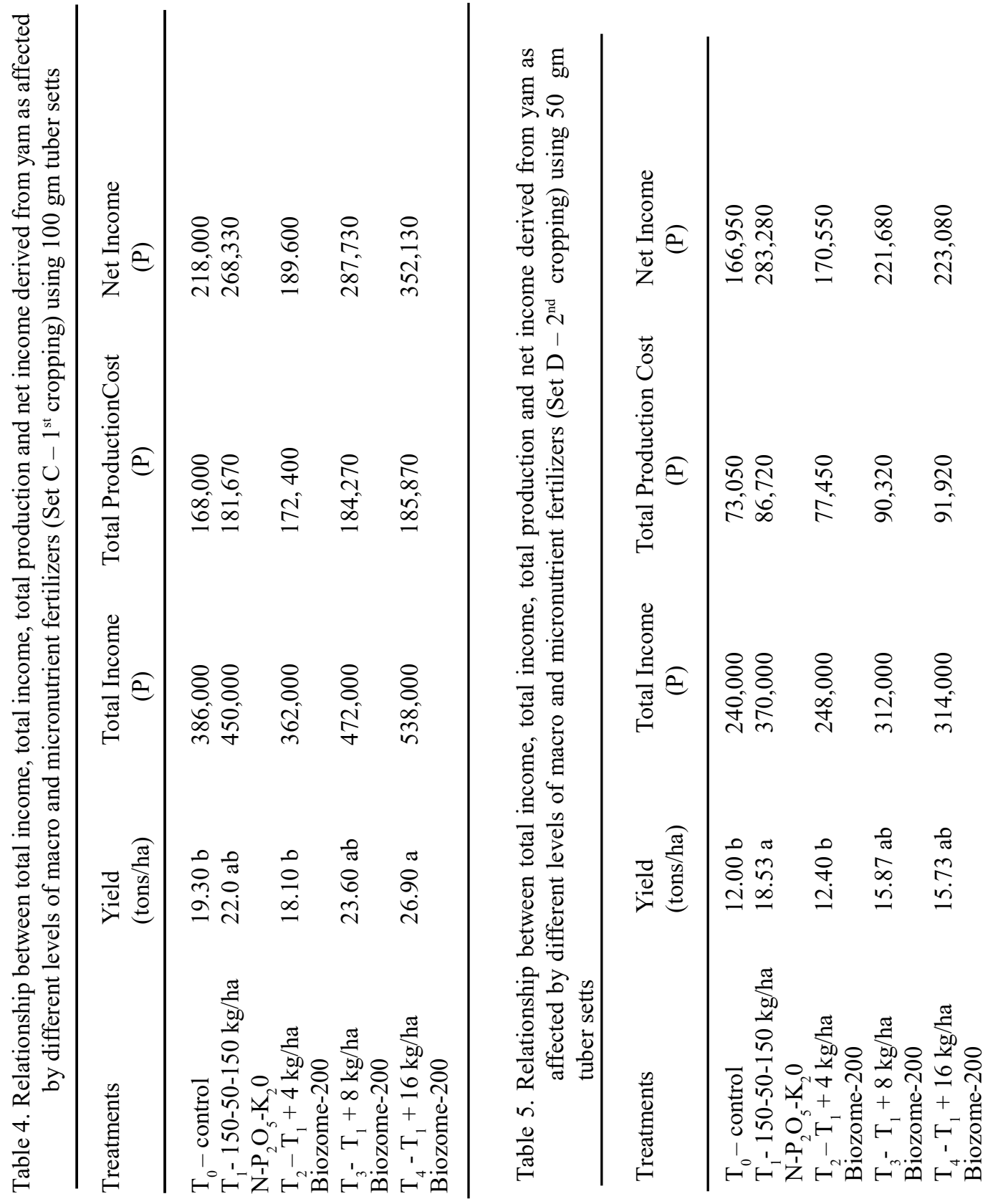
which used only $16 \mathrm{~kg} /$ ha of Biozome - $200\left(\mathrm{~T}_{2}\right)$ without any macronutrient addition, the total tuber yield obtained was similar to that of the control $\left(\mathrm{T}_{0}\right)$. This implied that the addition of micronutrients alone is not enough to sustain higher tuber yields in yam. Plants need both the macro and micronutrients for their growth and development. Although the cost of production was reduced by $\mathrm{P} 13,370$ (value obtained by deducting the cost of production in $\mathrm{T}_{4}$ and $\mathrm{T}_{2}$ ), the difference in tuber yield and net income is so big. The difference in total tuber yield is 5.5 tons/ha while that of the net income is about P107,000. When the tuber sett sizes was reduced into half from 100 (Set C) to $50 \mathrm{gm}$ in Set $\mathrm{D}$ (as presented in Tables 5 and 6), a similar results was obtained in Set B wherein the yield was also reduced from 23.6 tons /ha in Set C to 15.74 tons/ha in Set D. As for the effects of micronutrients addition without macronutrients, the results obtained were also similar to the control (Table 6). Likewise the reduction in tuber setts sizes also caused great reduction in the net income obtained.

On the other hand, when the levels of macronutrient fertilizers were reduced by half, significant reduction in total tuber yield and total net income were obtained even with the use of $100 \mathrm{gms}$ tuber setts (Table 7 and 8). The highest yield was only 14.77 tons/ha with a net income of 109,530 for $T_{4}$, while the total tuber yield in the control was only 7.37 tons/ha with a negative net income of -P20,600 (Table 7). This findings again support the previous results on yam that it needs high amount of $\mathrm{N}$ and $\mathrm{K}$ fertilizers for the development of its tubers. In Table 8, however a relatively higher yield was obtained even with reduced NPK fertilization. The area planted to yam was still relatively fertile because this was previously planted to aroids which also received sufficient amounts of NPK fertilizers. It is probable that there are still residual nutrients from previous cropping that was utilize by yam for its growth and development and this added to the amounts of macronutrients and micronutrients applied.

Regarding the effects of macro and micronutrient application on the individual tuber yield, results presented in Table 9 and Figure 4, showed that the addition of micronutrients to macronutrients indeed increased the individual tuber yield significantly even at lower levels of micronutrients applied at $4 \mathrm{~kg} / \mathrm{ha}$ of Biozome-200. Micronutrients 


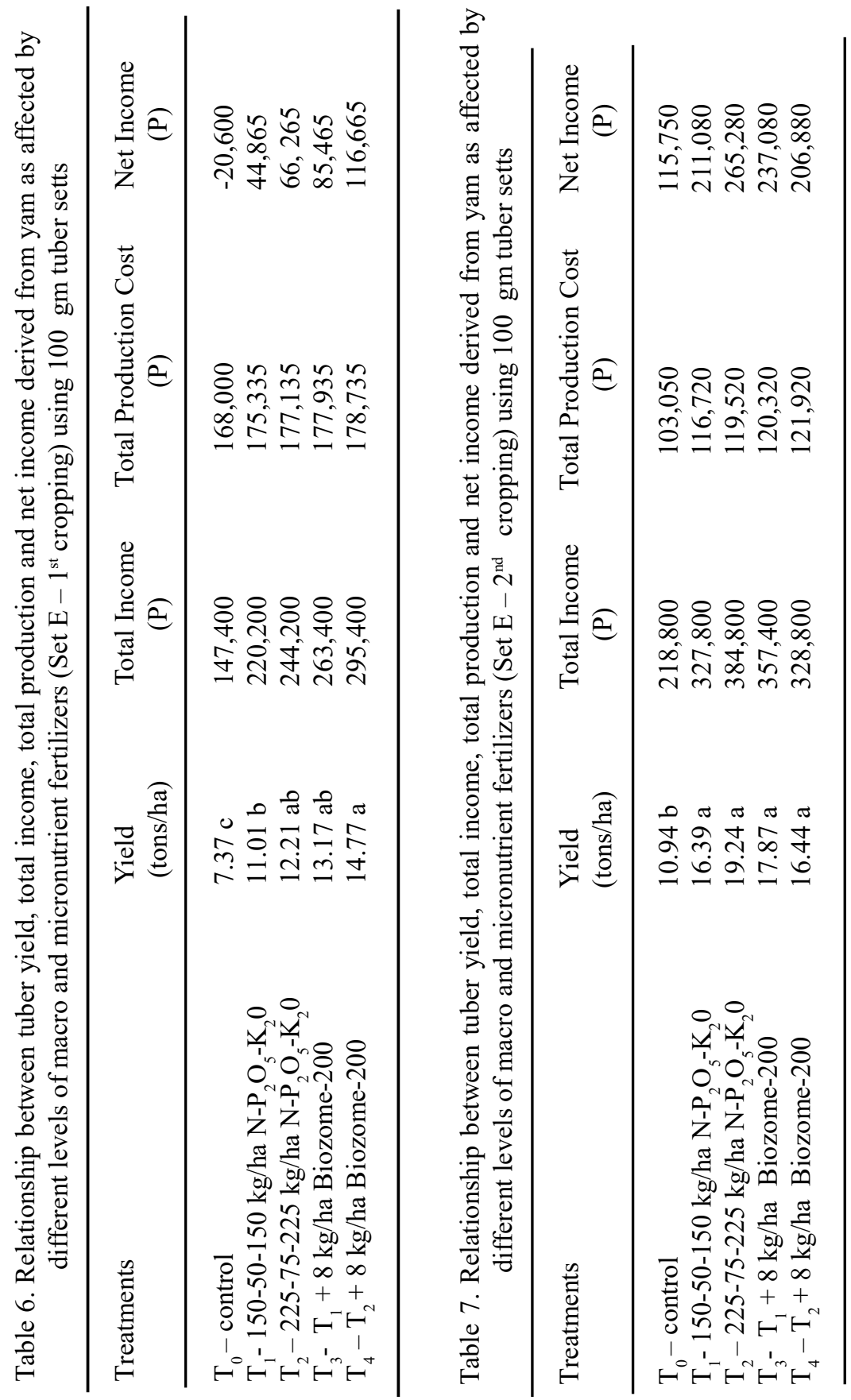



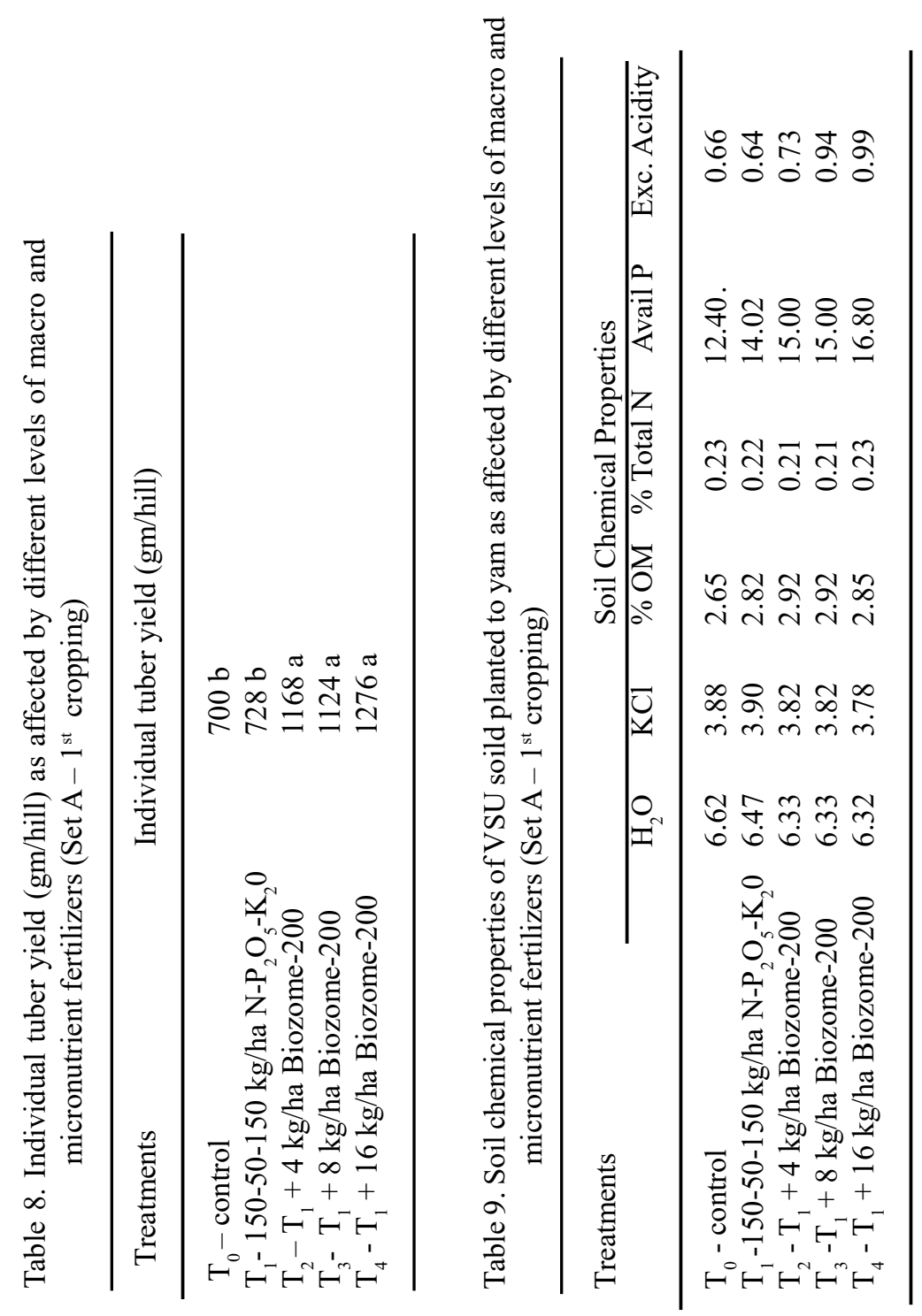
especially $\mathrm{Cu} . \mathrm{Mn}, \mathrm{Zn}$, and $\mathrm{B}$ are particularly involved in the reproductive phase of plant growth and development (Kirkby and Roemheld, 2004). Thus, bigger tubers were obtained in $\mathrm{T}_{3}$ and $\mathrm{T}_{4}$ as compared to the $\mathrm{T} 0$ and those applied with macronutrients only as shown in $\mathrm{T}_{1}$ (Figure 4). These findings was supported by the results of Malakouti and Tehrani (2005) and Malakouti (2007) which indicated that the application of micronutrient fertilizers to micronutrient deficient soils is associated with improved yield and crop quality for cereals, corn, beans, forages and oil seeds. Likewise Fertilizer Use Efficiency (FUE) for different crops can be increased by the application of micronutrients. In potato the average yield increase due to micronutrient fertilizer application was $13 \%$ (Malakouti , 2008).

\section{Effects of macro and micronutrients application on the tissue nutrient concentration of purple yam}

Aside from studying the effects of the application of the application of macro and micronutrients on yield and income of yam, additional data were also gathered on plant tissues like the leaves to further support our findings on its effect on plant growth. Results presented in Figures 5 and 6 obtained for Set E second cropping indicated that the application of macro and micronutrient fertilizers increases the amounts of total $\mathrm{N}$ and total $\mathrm{K}$ in the leaves of purple yam. This is very important in the development of tubers in yam since potassium is one of the limiting nutrients affecting the root development of rootcrops. In the study of Bautista and Santiago (1981), it was shown that the application of higher levels of potassium significantly affected the tuberization of sweetpotato. Aside from $\mathrm{N}$ and $\mathrm{K}$, the amounts of total $\mathrm{P}, \mathrm{Fe}, \mathrm{Mn}, \mathrm{Zn}$ and $\mathrm{Cu}$ likewise increased with addition of macro and micronutrient fertilizers. These findings further confirmed the significant contribution of macro and micronutrients in the growth and development of crops.

Effects of macro and micronutrients on soil chemical properties

Planted to purple yam

Results of soil chemical analyses conducted for Set A first cropping and Set E first cropping, revealed interesting findings on the effects of 


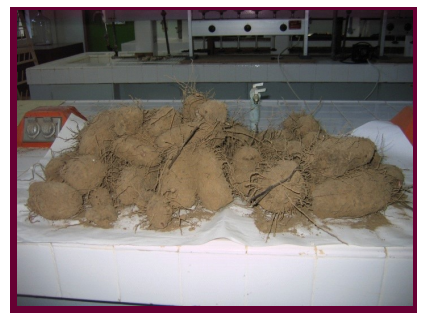

$\mathrm{T}_{0}$

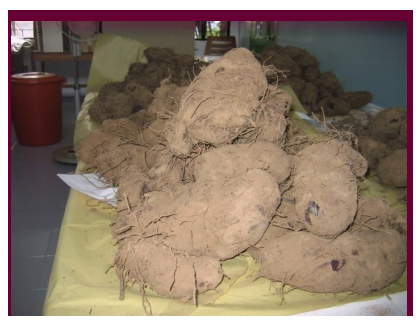

$\mathrm{T}_{3}$

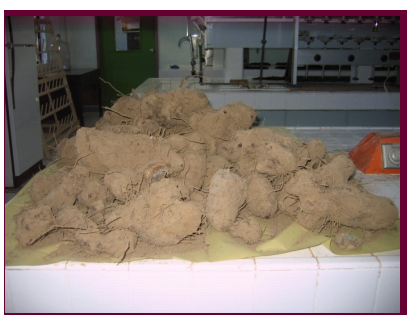

$\mathrm{T}_{1}$

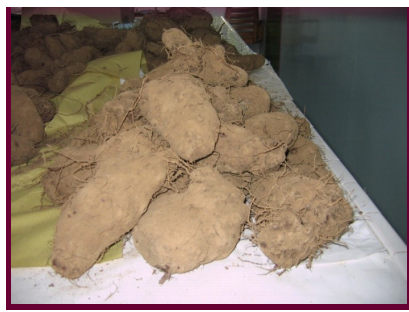

$\mathrm{T}_{4}$

Figure 4. Effects of macro and micronutrient fertilizers on the tuber sizes of purple yam (Set E, second cropping) 


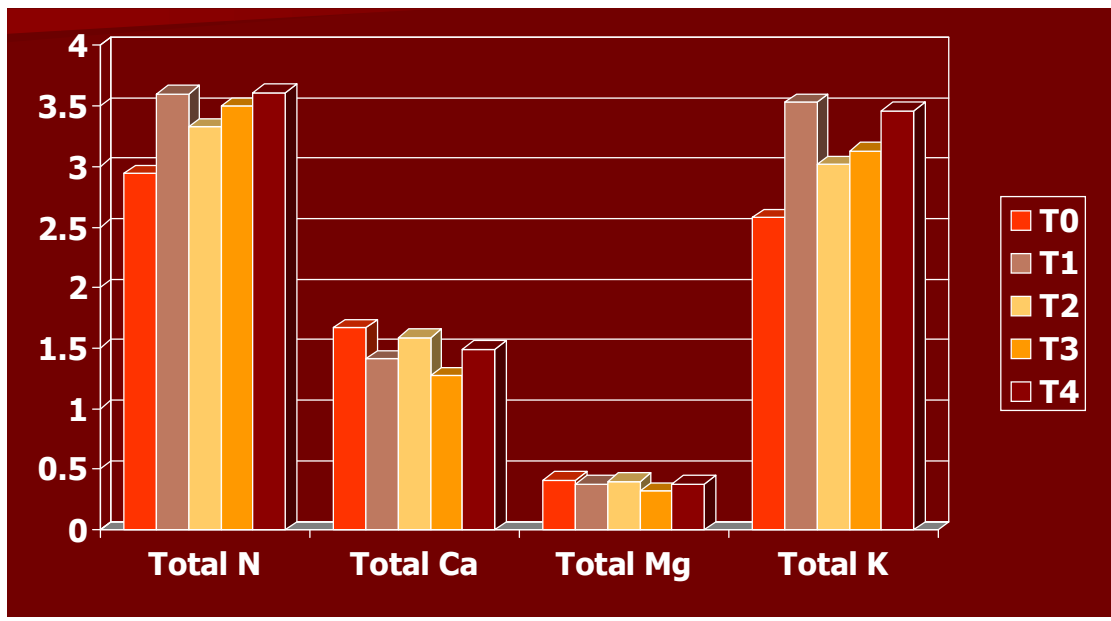

Figure 5. Amounts (\%) of total $\mathrm{N}, \mathrm{Ca}, \mathrm{Mg}$, and $\mathrm{K}$ in plant tissue (leaves) of purple yam as affected by different levels of macro and micronutrient fertilizers (Set E, 2nd cropping)

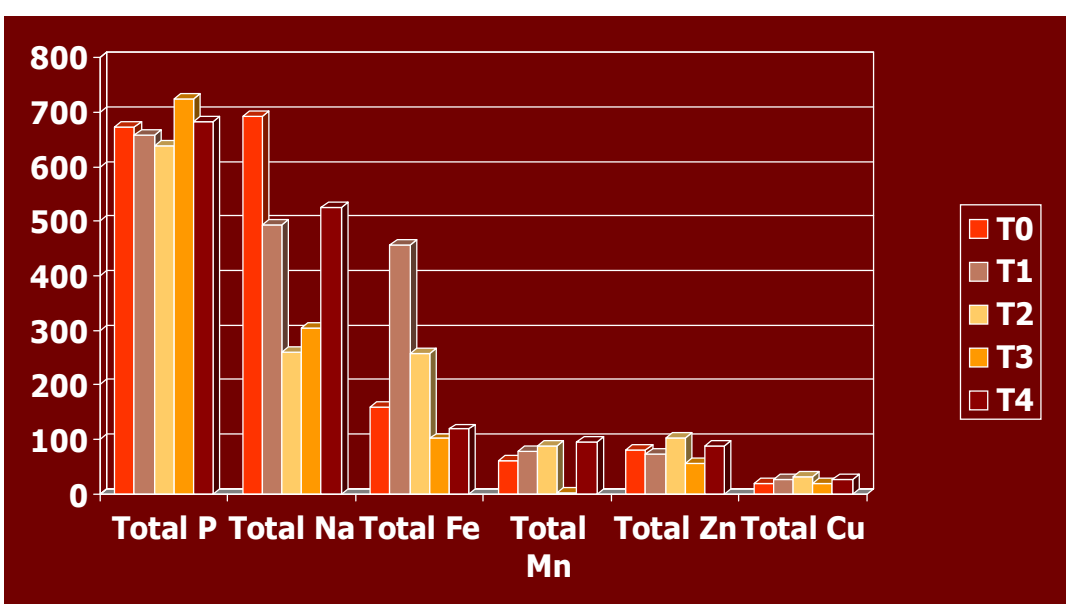

Figure 5. Amounts (ppm) of total P,total $\mathrm{Na}$, Total $\mathrm{Fe}$, total $\mathrm{Mn}$, Total $\mathrm{Zn}$, and total $\mathrm{Cu}$ in plant tissue (leaves) of purple yam as affected by different levels of macro and micronutrient fertilizers (Set E, 2nd cropping) 
Table 10. Soil chemical properties of VSU soil planted to yam as affected by different levels of macro and micronutrient fertilizers (Set E - 1st cropping)

\begin{tabular}{lllll}
\hline Treatments & $\begin{array}{l}\text { Soil } \mathrm{pH} \\
(1: 2.5)\end{array}$ & $\begin{array}{l}\text { Avail } \mathrm{P} \\
(\mathrm{mg} / \mathrm{kg})\end{array}$ & $\begin{array}{l}\text { Total } \mathrm{N} \\
(\%)\end{array}$ & $\begin{array}{l}\text { Exch. K } \\
(\mathrm{mg} / \mathrm{kg})\end{array}$ \\
\hline $\mathrm{T}_{0}$ - control & $5.91 \mathrm{a}$ & 23.93 & 0.08 & 248.55 \\
$\mathrm{~T}_{1}-150-50-150 \mathrm{~kg} / \mathrm{ha}$ & $5.49 \mathrm{~b}$ & 28.11 & 0.08 & 255.02 \\
$\mathrm{~N}-\mathrm{P}_{2} \mathrm{O}_{5}-\mathrm{K}_{2} \mathrm{O}$ & & & & \\
$\mathrm{T}_{2}-225-75-225 \mathrm{~kg} / \mathrm{ha}$ & $5.53 \mathrm{~b}$ & 28.59 & 0.08 & 238.13 \\
$\mathrm{~N}-\mathrm{P}_{2} \mathrm{O}_{5}-\mathrm{K}_{2} \mathrm{O}$ & & & & \\
$\mathrm{T}_{3}-\mathrm{T}_{1}+8 \mathrm{~kg} / \mathrm{ha}$ & $5.54 \mathrm{~b}$ & 27.82 & 0.08 & 254.88 \\
$\mathrm{Biozome}-200$ & & & & \\
$\mathrm{~T}_{4}-\mathrm{T}_{2}+8 \mathrm{~kg} / \mathrm{ha}$ & $5.55 \mathrm{~b}$ & 25.82 & 0.09 & 211.63 \\
Biozome-200 & & & & \\
\hline
\end{tabular}

macro and micronutrients on the various soil chemical properties such as soil $\mathrm{pH}$, organic matter, available $\mathrm{P}$, exchangeable acidity, exchangeable $\mathrm{Na}, \mathrm{Mn}, \mathrm{Cu}$ and $\mathrm{Zn}$ (Tables 10 to 12 ).

The beneficial effects include the increase in the amount of organic matter, available $\mathrm{P}$, exchangeable acidity due to slight reduction in soil $\mathrm{pH}$, and exchangeable $\mathrm{Zn}$ (Table 9, 10 and 12). The application of $16 \mathrm{~kg} /$ ha Biozome-200 $\left(\mathrm{T}_{4}\right)$ in Set E increases the amounts of exchangeable $\mathrm{Ca}, \mathrm{Mg}, \mathrm{Na}, \mathrm{Mn}$ and $\mathrm{Cu}$ in the soil(Table 11 and 12). These findings supported the higher amounts of nutrients extracted in the leaves and tubers of purple yam. Thus the addition of small amounts of micronutrients contributed much in improving the nutrient supplying capacity of the soil which directly enhanced the growth and yield of purple yam. Another important contribution of micronutrient addition is the slight reduction in soil $\mathrm{pH}$ value which is very important in the development of purple coloration in yam. In our previous findings, we have shown that acid soils produced dark colored yams as compared to neutral or alkaline soils (Loreto et al., 2002) . Normally, the darker the purple coloration in yam the greater would be its demand in the market. Pure purple yam also has high anthocyanin and micronutrients content which made them very attractive as health and food products. 
Table 11. Soil chemical properties of VSU soil planted to yam as affected by different levels of macro and micronutrient fertilizers (Set $\mathrm{E}-1^{\text {st }}$ cropping)

\begin{tabular}{lllll}
\hline Treatments & $\begin{array}{l}\text { Exch. Ca } \\
(\mathrm{mg} / \mathrm{kg})\end{array}$ & $\begin{array}{l}\text { Exch. Mg } \\
(\mathrm{mg} / \mathrm{kg})\end{array}$ & $\begin{array}{l}\text { Exch. Na } \\
(\mathrm{mg} / \mathrm{kg})\end{array}$ & $\begin{array}{l}\text { Exch. Mn } \\
(\mathrm{mg} / \mathrm{kg})\end{array}$ \\
\hline $\mathrm{T}_{0}$-control & 2599 & 624 & 41.04 & 62.64 \\
$\begin{array}{l}\mathrm{T}_{1}-150-50-150 \mathrm{~kg} / \mathrm{ha} \\
\mathrm{N}-\mathrm{P}_{2} \mathrm{O}_{5}-\mathrm{K}_{2} \mathrm{O}\end{array}$ & 2381 & 564 & 36.97 & 60.82 \\
$\begin{array}{l}\mathrm{T}_{2}-225-75-225 \mathrm{~kg} / \mathrm{ha} \\
\mathrm{N}-\mathrm{P}_{2} \mathrm{O}_{5}-\mathrm{K}_{2} \mathrm{O}\end{array}$ & 2444 & 563 & 26.19 & 56.81 \\
$\begin{array}{l}\mathrm{T}_{3}-\mathrm{T}_{1}+8 \mathrm{~kg} / \mathrm{ha} \\
\text { Biozome -200 }\end{array}$ & 2277 & 521 & & \\
$\begin{array}{l}\mathrm{T}_{4}-\mathrm{T}_{2}+8 \mathrm{~kg} / \mathrm{ha} \\
\text { Biozome-200 }\end{array}$ & 2381 & & 36.99 & 61.73 \\
\hline
\end{tabular}

Table 12. Soil chemical properties as affected by different levels of macro and micronutrient fertilizers (Set $\mathrm{E}-1^{\text {st }}$ cropping)

\begin{tabular}{llll}
\hline Treatments & $\begin{array}{l}\text { Exch. Cu } \\
(\mathrm{mg} / \mathrm{kg})\end{array}$ & $\begin{array}{l}\text { Exch. Zn } \\
(\mathrm{mg} / \mathrm{kg})\end{array}$ & $\begin{array}{l}\text { Exch. Fe } \\
(\mathrm{mg} / \mathrm{kg})\end{array}$ \\
\hline $\mathrm{T}_{0}-$ control & 13.25 & $25.68 \mathrm{bc}$ & 753 \\
$\mathrm{~T}_{1}-150-50-150 \mathrm{~kg} / \mathrm{ha}$ & 12.59 & $22.89 \mathrm{c}$ & 743 \\
$\mathrm{~N}-\mathrm{P}_{2} \mathrm{O}_{5}-\mathrm{K}_{2} 0$ & & \\
$\mathrm{~T}_{1}-225-75-225 \mathrm{~kg} / \mathrm{ha}$ & 12.17 & $27.41 \mathrm{ab}$ & 741 \\
$\mathrm{~N}-\mathrm{P}_{2} \mathrm{O}_{5}-\mathrm{K}_{2} 0$ & & & \\
$\mathrm{~T}_{3}-\mathrm{T}_{1}+8 \mathrm{~kg} / \mathrm{ha}$ & 11.53 & $29.82 \mathrm{ab}$ & 741 \\
Biozome-200 & & & \\
$\begin{array}{l}\mathrm{T}_{4}-\mathrm{T}_{2}+8 \mathrm{~kg} / \mathrm{ha} \\
\text { Biozome-200 }\end{array}$ & 14.71 & $31.01 \mathrm{a}$ & 752 \\
\hline
\end{tabular}




\section{CONCLUSIONS}

From the results of this project covering 7 cropping seasons in a span of five years, the following conclusions can be drawn:

1. There is a direct relationship between the application of macro and micronutrient fertilizers on the total tuber yield and net income that can be derived from purple yam production.

2. Total tuber yields ranging from 15 tons to 26 tons/ha could be achieved through the application of macro and micronutrients fertilizers using $100 \mathrm{gm}$ tuber setts as planting materials. This is equivalent to about 300 to $500 \%$ increase in yield from the reported national average of 5 tons/ha.

3. This likewise increased the net income obtained up to more than P250,000 per cropping of purple yam through the application of 150-50$150 \mathrm{~kg} / \mathrm{ha} \mathrm{N}-\mathrm{P}_{2} \mathrm{O}_{5}-\mathrm{K}_{2} \mathrm{O}$ and $4-16 \mathrm{~kg} / \mathrm{ha}$ Biozome- 200 .

4. It also improves the total nutrient content of plant tissue (leaves) especially the amounts of $\mathrm{N}$ and $\mathrm{K}$ which are important for the development of purple yam tubers.

5. In terms of soil properties, the addition of macro and micronutrients slightly reduced the $\mathrm{pH}$ of the soil which is important in enhancing the intensity of purple coloration in yam. The application of $16 \mathrm{~kg} / \mathrm{ha}$ Biozome-200 increases the amounts of organic matter, available $\mathrm{P}$, exchangeable $\mathrm{Ca}, \mathrm{Na}, \mathrm{Mn}, \mathrm{Cu}$ and $\mathrm{Zn}$ in the soil.

6. Micronutrients addition also improves the nutrient content of purple yam which would give added value to purple yam especially in the promotion of this crop as a high value commodity.

7. In terms of tuber sett sizes, the reduction in the size of tuber setts from 100 gms to 50 gms also reduced the yield obtained by almost half.

8. Reduction in the amounts of NPK fertilizers from 150-50-150 N - $\mathrm{P}_{2} \mathrm{O}_{5}-\mathrm{K}_{2} \mathrm{O}$ to $75-25-75 \mathrm{~N}-\mathrm{P}_{2} \mathrm{O}_{5}-\mathrm{K}_{2} \mathrm{O}$ will likewise reduce the yield and net income that can be derived from purple yam production.

9. The application of micronutrients alone without macronutrient is not sufficient to improve the growth and yield of yam. This should be applied in combination with NPK fertilizer since it will enhance the efficiency of macronutrient fertilization. 


\section{REFERENCES}

BAUTISTA, A.T. and R.M. SANTIAGO. 1981. Growth and yield of sweet potato as influenced by different potassium levels in three soil types. Ann. Trop. Res. 3(3): $177-186$

BELL, R.W. , B. DELL and L. HUANG. 2004. Importance of Micronutrients in Crop Nutrition. Paper presented during the IFA International Symposium on Micronutrients held at New Delhi, India on February 23-25, 2004.

www.fertilizer.org/ifa/events/ifa/PDF/ifa_ag_2004_02_programme.pdf

COURSEY, D.G. 1967. Yams. Longmans, London, England, 230pp.

DIBY, L.N., R. CARSKY, A. ASSA, TIE B. TRA, O. GIRARDIN and E. FROSSARD. 2004. Understanding soil factors limiting the potential yield of yam (Dioscorea spp.). http://www.copscience.org.au/icsc2004/poster/2/3/322_dibyl.htm.

INTERNATIONAL SOIL REFERENCE AND INFORMATION CENTER (ISRIC). 1995. Procedures for Soil Analysis . Wageningen, The Netherlands. 106 pp.

IRIZARRY, H. and RIVERA, E. 1985. Nutrient uptake and dry matter production by intensively managed yams grown in Ultisols. J. Agric. Univ. Puerto Rico 69:1-9.

JACKSON, M. L. 1958. Soil Chemical Analysis. Prentice Hall, Inc. New Jersey. 488pp.

KABEERATHUMMA, S., B. MOHANKUMAR, and P. G. NAIR.1987. Nutrient uptake and their utilization by yams aroids and coleus. Tech. Bull. Series 10, CTCRI, Thiruvanantapuram, Kerala, India.

KIRKBY, E.A. and V. ROEMHELD. 2004. Micronutrients in Plant Physiology: Functions, Uptake and Mobility. Proceedings of the International Fertilizer Society. P O Box 4, York YO32 5YS,UK.

LORETO, D.P., C.D.V.GODOY and A.B. TULIN. 2002. Growth performance and tuber coloration of yam as affected by soil $\mathrm{pH}$. Paper presented in the local Science Fair held at Leyte State University, Visca, Baybay, Leyte on January 2023,2002.

MALAKOUTI, M.J. 2008. The effect of micronutrients in ensuring efficient use of macronutrients. Turk. J. Agric. For. 32:215-220.

MALAKOUTI, M. J. 2007. Zinc is a neglected element in the life cycle of plants: a review. Middle East. Rus. J. Plant Sci. and Biotech. 1:1-12.

MALAKOUTI, M.J. and M.M. TEHRANI. 2005. Effects of micronutrient on the yuield and quality of agricultural products. Micronutrient with macro-effects. Tarbiat Modares University Press. Tehran, Iran. P.445. 
MURPHY, J. and J.P. RILEY. 1962. A modified single solution method for the determination of phosphorus in natural water. Anal. Chem. Acta. 27: 31-36.

MYLAVARAPU, R.S. and E.D. KENNELLEY. 2002. UF/IFAS Extension Soil Testing Laboratory (ESTL) Analytical Procedures and Training Manual. http:/ edis.ifas.ufl.edu/SS312.

ONWUEME, I.C. 1978. Tropical Tuber Crops. John Wiley and Sons, New York. Pp.3106.

O'SULLIVAN, J.N., C.J. ASHER and F.P.C. BLAMEY. 1997. Nutrient disorders of sweet potato. ACIAR Monograph No. 148, 136p.

PIDO, N. L. 1997. Ubi Production: Practices and Technology Update. Paper presented during the Seminar-Workshop on Ubi held at the Philippine Trade and Training Center, metro Manila on October 14, 1997.

PCARR, 1980. Standard Methods of Analysis for Soil, Plant Tissue, Water, and Fertilizers. Philippine Council for Agriculture and Resources Research. College of Agriculture, Los Baños, Laguna, Philippines.

SCHLICHTING, E., H.P. BLUME and K. STAHR. 1995. Soil Science Practicum. 2nd ed. Blackwell, Berlin. 295 pp.

SCOTT, G.J., R. BEST, M. ROSEGRANT, and M. BOKANGA. 2000. Roots and tubers in the global food system: A vision statement of the year 2020. A co-publication of the International Potato Center (CIP), Centro International de Agricultura Tropical (CIAT), International Food Policy Research Institute (IFRI), International Institute of Tropical Agriculture (IITA), and International Plant Genetic Resources Institute (IPGRI). Printed in Lima, Peru: International Potato Center.

TULIN, A. B., V. B. ASIO, D. M. CAMPILAN and S. KAwAI. 2004. Farmer's scientists participatory identification of nutrient deficiency symptoms in sweetpotato. Ann. Trop. Res. 26 (1\& 2): 61-114.

VILLAREAL, R. L., S. C. TSUO, H. F. LO and S.C. CHIU. 1985. Sweetpotato vine tips as vegetables. In: Bouwkamp, J. C. ed., Sweet Potato Products: a natural resource for the Tropics. CRC Press, Boca Raton, Florida, 175-183.

WOOLFE, J. A. 1992. Sweet potato: an untapped food resource. Cambridge University Press. 